
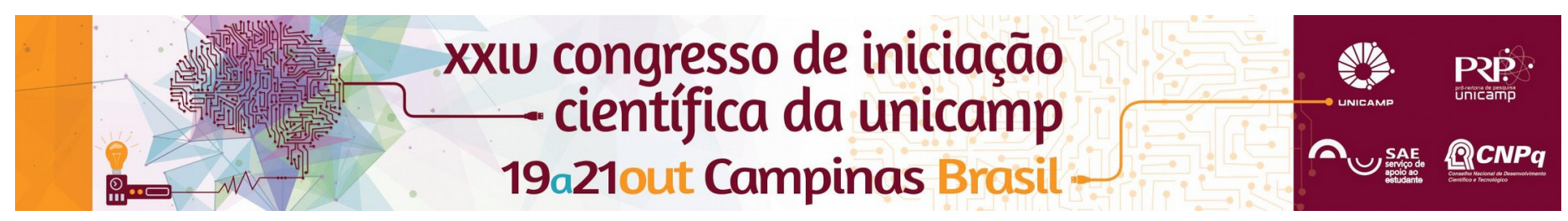

\title{
O CONHECIMENTO GEOGRÁFICO NA IDADE MÉDIA. AS TRANSFORMAÇÕES METODOLÓGICAS E EPISTEMOLÓGICAS SOBRE A NATUREZA NOS SÉCULOS XII E XIII E O SEU PAPEL NA CONCEPÇÃO DE GEOGRAFIA
}

\section{Damião Silva Santos*}

\section{Resumo}

As modificações socieconômicas ocorridas nos séculos XII e XIII devido ao Renascimento Comercial e Industrial permitiram a urbanização das cidades medievais e a criação das Universidades, promovendo o surgimento de uma formulação teórica sobre a ciência, que servirá de fundamento para a inovação técnica na Modernidade, conduzindo a uma reinterpretação e compreensão geográfica sobre a natureza, espaço e mundo na contemporaneidade.

\section{Palavras-chave: \\ Ciência, Geografia, Cosmologia \\ Introdução}

Entre os séculos XII e XIII há um Renascimento Comercial e Industrial, ressurgindo as cidades medievais e a criação das Universidades. A partir disso, o presente trabalho tem como objetivo estudar as modificações intelectuais, teológica e filosófica na Idade Média dos séc. XII e XIII, as quais promoveram o surgimento de uma formulação teórica sobre a ciência, servindo de fundamento para a inovação técnica na Modernidade, conduzindo a uma reinterpretação e compreensão geográfica sobre a Natureza Mundo.

\section{Resultados e Discussão}

O período medieval é conceituado como "Idade das Trevas", porque acredita-se que nele não houve produção intelectual científica. Entretanto, é possível afirmar que houve uma intensa atividade teológica filosófica na Idade Média, cujos fundamentos foram a filosofia grega helênica, greco-árabe e a teologia cristã possibilitando na Idade Moderna, a concepção da Ciência Contemporânea.

Como comprovação disso, é a atual conceituação cosmológica sobre o Universo, infinito e sem centralidade, para chegar a esse conceito científico, abandonou-se o modelo geocêntrico medieval, aristotélico ptolomaico, qualitativo finito, e também o heliocêntrico moderno, ptolomaico copernicano, quantitativo finito, século XVI, adotando-se a cosmologia newtoniana, quantitativa infinita, século XVIII.

O mesmo processo citado acima aconteceu com o conceito de espaço, já que na Idade Média a visão teológica cristã concebia a Terra retangular e imutável. Com a metodologia científica de GROSSETESTE e RÓGER BACON séc. XII e XIII, baseada no sentido, observação, experiência e no experimento, constata-se que matéria corpórea é mutável, quantitativa e perceptível espacialmente.

Esta concepção pode ser conectada aos experimentos científicos das transformações das substâncias na espacialidade na Modernidade dos séc. XVI e XVII, fazendo NEWTON no séc. XVIII, concluir que o espaço é tridimensional, quantitativo e absoluto em si mesmo, constituindo o Mundo Universo.
Figura 1. Cosmologia aristotélica ptolomaica idade média.

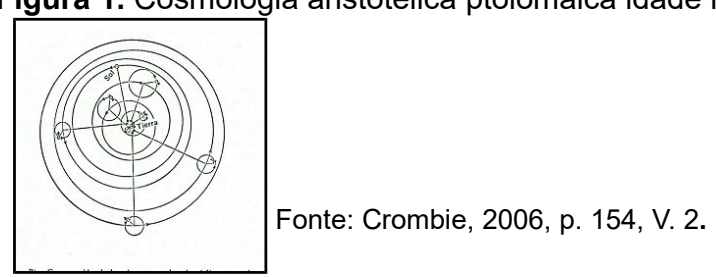

Figura 2. Cosmologia ptolomaica copernicana idade moderna.

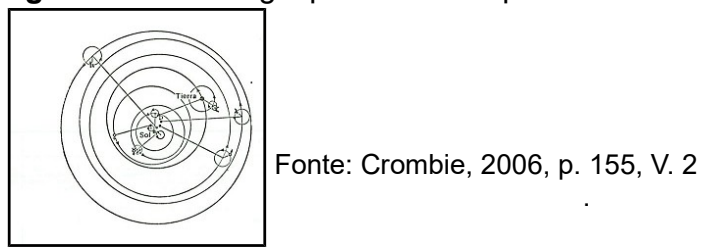

Figura3: Cosmologia newtoniana contemporânea

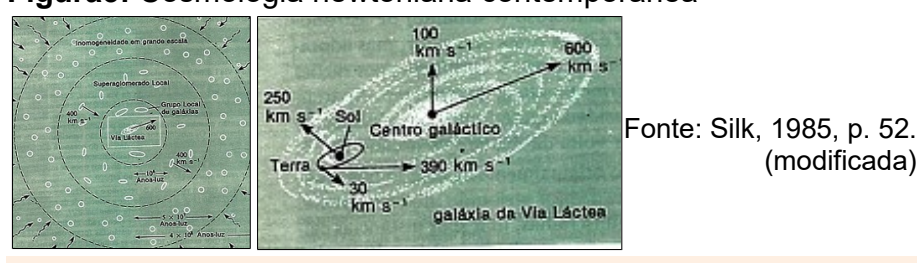

\section{Conclusão}

Pode ser dito, que houve uma evolução em relação a concepção da natureza do espaço mundo, que durante a Idade Média foi concebido em conceitos filosóficos teológicos, uma visão espacial qualitativa, e que a partir da modernidade científica passa a ser quantificado, em modelos matemáticos experienciáveis, incorporados a contemporaneidade.

CROMBIE, A. C. Historia de la Ciencia: De San Agustín a Galileo. Madrid: Alianza Editorial, 2006.

FRANCO JÚNIOR, H. A Idade Média: nascimento do ocidente. São Paulo: Brasiliense, 2004, 201p.

GRANT, E. Os fundamentos da Ciência Moderna na Idade Média. Tradução de Carlos Grifo Babo. Porto: Porto Editora, 2002.

KOBUSCH, T (Org.). Filósofos da Idade Média: uma Introdução. Tradução de Paulo Astor Soethe. São Leopoldo: Unisinos, 2005.

NASCIMENTO, C. A. R. De Tomás de Aquino a Galileu. Campinas: IFCH Instituto de Filosofia e Ciências Humanas Unicamp, 1995.

SILK, J. O Big Bang: a origem do universo. Tradução de Fernando Dídimo Pereira Barbosa Vieira. Brasília: Editora Universidade de Brasília, 1985, 400p. 